\title{
Autolysis of Bacterial Cells Capable of Producing Lytic Enzyme
}

\author{
Isao Sugahara, * Koichiro Hayashi,* Toshio Kimura, ${ }^{*}$ \\ Chikara Jinno,* and Naohiro Higashioka* \\ (Accepted August 21, 1985)
}

\begin{abstract}
The autolysis of bacterial cells (strain V37) capable of producing lytic enzyme was investigated using the washed cells grown in polypepton-yeast extract medium.

Strain V37 cells grown in the medium containing $0.5 \mathrm{M} \mathrm{NaCl}$ or $\mathrm{KCl}$ were conspicuously autolysed than those grown in the medium comprising $0.5 \mathrm{M} \mathrm{MgCl}_{2}$ or without addition of any inorganic salt. The optimum $\mathrm{pH}$ and temperature for the autolysis of strain V37 cells were 7 to 9 and $40^{\circ} \mathrm{C}$, respectively. The autolytic activity slightly increased in the presence of $0.2-0.3 \mathrm{M} \mathrm{NaCl}$

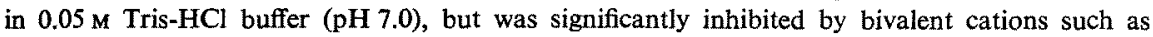
$\mathrm{Ba}^{2+}, \mathrm{Ni}^{2+}, \mathrm{Co}^{2+}$ and $\mathrm{Mg}^{2+}$. The presence of $\mathrm{NaCl}(0.4-0.9 \mathrm{M})$ in the medium enhanced their ability to autolyse.
\end{abstract}

Autolytic enzyme (autolysin) is indispensable for the bacterial growth. Autolysins of Bacillus sp. are used during the growth process to open gaps in the cell wall in order to permit surface expansion and also used to separate linked daughter cells after septum formation. ${ }^{1,2)}$ The autolysins seem to be involved in transformation by externally added deoxyribonucleic acid, ${ }^{3)}$ in turnover of bacterial wall polymers and also in spore formation etc. ${ }^{4}$ )

The bacterium (named strain V37) isolated from coastal waters extracellulary produced bacteriolytic as well as proteolytic enzymes when aerobically grown at $30^{\circ} \mathrm{C}$ in polypepton-yeast extract medium containing $\mathrm{NaCl}$ or $\mathrm{KCl}^{5-7)}$ On the other hand, strain V37 cells, harvested during the growth from the early log to the middle log phases, exhibited a remarkable autolytic activity, although no significant autolysis was observed in the stationary-phase cells. ${ }^{8}$ ) High concentration $(2.0 \mathrm{M})$ of $\mathrm{NaCl}$ or low concentration $(0.05 \mathrm{M})$ of $\mathrm{Mg}^{2+}$ considerably inhibited the autolytic activity of strain V37 cells grown in the medium containing $\mathrm{NaCl}(0.5 \mathrm{M}){ }^{\text {8) }}$

The similarity between extracellular lytic enzyme and autolytic enzyme of strain V37 on the $\mathrm{NaCl}$ dependence is very interesting. Although lytic enzyme was accumulated in the culture supernatant fraction of culture fluids in the course of growth of strain V37, it has not yet been demonstrated whether intracellular lytic enzyme was liberated as a result of cell autolysis or whether autolytic enzyme (autolysin) itself was released from cells during the growth. The physiological significance of extracellular lytic enzyme and autolytic enzyme of strain V37 is not well understood.

The present study was designated to obtain preliminary information concerning autolysis of strain V37 cells capable of producing lytic enzyme.

\section{Methods}

Culture of Strain V37 Capable of Producing Lytic Enzyme

The medium used in this study was composed of polypepton (Daigo Eiyō Kagaku), 10.0 g: yeast extract (Nakarai Chemicals), $5.0 \mathrm{~g}$ : inorganic salt $\left(\mathrm{NaCl}, \mathrm{KCl}\right.$ or $\mathrm{MgCl}_{2}$ ), 0 or $0.5 \mathrm{~mol}$ and $1,000 \mathrm{ml}$ distilled water. The $\mathrm{pH}$ of the medium was adjusted to 7.0. The liquid medium was dispensed in $250 \mathrm{ml}$ portions into $500 \mathrm{ml}$ Sakaguchi flasks. Sterilization was done by means of autoclaving at $121^{\circ} \mathrm{C}$ for $15 \mathrm{~min}$. The Sakaguchi flask containing $250 \mathrm{ml}$ of the preculture medium without addition of any inorganic salt was inoculated with a loopful of strain V37, and incubated at $30^{\circ} \mathrm{C}$ for $24 \mathrm{~h}$ on reciprocating shaker with a shaking rate of 100 strokes per min. Each $1.0 \mathrm{ml}$ of strain V37 culture fluids from the preculture medium was aseptically transferred into the medium containing inorganic salt $(0.5 \mathrm{M} \mathrm{NaCl}$, $\mathrm{KCl}$ or $\mathrm{MgCl}_{2}$ ) or having no added inorganic salt. The inoculated flasks were incubated at $30^{\circ} \mathrm{C}$ on reciprocating shaker.

Assay of Autolytic Activity

After $4-7 \mathrm{~h}$ cultivation ( $\mathrm{OD}_{670} ;$ about $0.20-0.30$ )

* Faculty of Fisheries, Mie University, Tsu 514, Japan（菅原 庯，林孝市郎，木村俊夫，神野 力，東岡 修弘: 三重大学水産学部). 


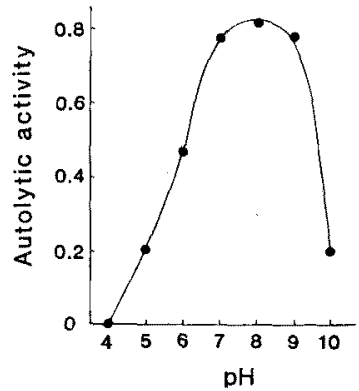

Fig. 1. Effect of pH value on the autolytic activity of strain V37 cells grown in polypepton-yeast extract medium containing $0.5 \mathrm{M} \mathrm{NaCl}$.

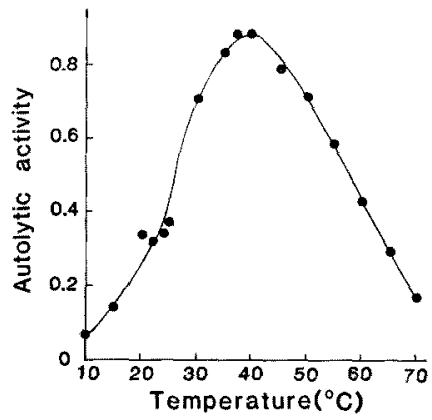

Fig. 2. Effect of temperature on the autolytic activity of strain V37 cells grown in polypepton-yeast extract medium containing $0.5 \mathrm{M} \mathrm{NaCl}$.

of strain V37, the cells were harvested at $0^{\circ} \mathrm{C}$ by centrifugation. The harvested cells of strain V37 were washed once in $0.05 \mathrm{M}$ Tris- $\mathrm{HCl}$ buffer ( $\mathrm{pH}$ 7.0) containing inorganic salt to be tested, and suspended in similar solution so as to produce an absorbance of about 1.00 at $570 \mathrm{~nm}$. The assay was carried out at $40^{\circ} \mathrm{C}$ for $30 \mathrm{~min}$, unless otherwise described. The optical density at $570 \mathrm{~nm}$ of the cell suspension was determined at fixed intervals of time. The autolytic activity was represented as a decrease in absorbance at $570 \mathrm{~nm}$ in $30 \mathrm{~min}$. The lysis of cells heated at $100^{\circ} \mathrm{C}$ for $10 \mathrm{~min}$ was also determined as a control. The control value was very low in all the autolysis experiments carried out in this study.

\section{Results}

\section{Optimum pH for Autolytic Activity}

Strain V37 cells grown in the medium containing $0.5 \mathrm{M} \mathrm{NaCl}$ were washed once in $\mathrm{pH}$ buffer to be tested, and resuspended in similar buffer as that used for washing cells. The $\mathrm{pH}$ buffers used were as follows: $0.2 \mathrm{M}$ acetate buffer for $\mathrm{pH} 4.0$, 5.0 and 6.0, 0.05 $\mathrm{M}$ Tris- $\mathrm{HCl}$ buffer for $\mathrm{pH} 7.0,8.0$
Table 1. Effect of inorganic salts on the autolysis of strain V37 cells grown in polypepton-yeast extract medium containing $0.5 \mathrm{M} \mathrm{NaCl}, \mathrm{KCl}$ or $\mathrm{MgCl}_{2}$, and in the medium containing no in. organic salt

\begin{tabular}{lllll}
\hline \multirow{2}{*}{$\begin{array}{c}\text { Inorganic salt } \\
\text { in cell }\end{array}$} & \multicolumn{4}{c}{$\begin{array}{c}\text { Autolytic activity of cells grown } \\
\text { in medium containing }\end{array}$} \\
\cline { 2 - 6 } & $\begin{array}{c}0.5 \mathrm{M} \\
\text { Nuspension }\end{array}$ & $\begin{array}{c}0.5 \mathrm{M} \\
\mathrm{KCl}\end{array}$ & $\begin{array}{c}0.5 \mathrm{M} \\
\mathrm{MgCl}_{2}\end{array}$ & None \\
\hline $0.5 \mathrm{M} \mathrm{NaCl}$ & 0.837 & 0.824 & 0.354 & 0.309 \\
$0.5 \mathrm{M} \mathrm{KCl}$ & 0.633 & 0.668 & 0.251 & 0.225 \\
$0.5 \mathrm{M} \mathrm{LiCl}$ & 0.620 & 0.791 & 0.320 & 0.212 \\
$0.5 \mathrm{M} \mathrm{CsCl}$ & 0.760 & 0.852 & 0.154 & 0.234 \\
$0.5 \mathrm{M} \mathrm{RbCl}$ & 0.612 & 0.649 & 0.360 & 0.245 \\
$0.5 \mathrm{M} \mathrm{NaNO}_{3}$ & 0.609 & 0.736 & 0.292 & 0.196 \\
$0.5 \mathrm{M} \mathrm{NH} \mathrm{Cl}^{2}$ & 0.824 & 0.848 & 0.116 & 0.137 \\
\hline $0.5 \mathrm{M} \mathrm{MgCl}_{2}$ & 0 & 0 & 0 & 0 \\
$0.5 \mathrm{M} \mathrm{CaCl}_{2}$ & 0 & 0 & 0 & 0 \\
$0.5 \mathrm{M} \mathrm{BaCl}_{2}$ & 0 & 0 & 0 & 0 \\
\hline $0.5 \mathrm{M} \mathrm{Na}_{2} \mathrm{SO}_{4}$ & 0 & 0 & 0.091 & 0.020 \\
$0.5 \mathrm{M} \mathrm{K}_{2} \mathrm{SO}_{4}$ & 0 & 0 & 0.085 & 0.059 \\
$0.5 \mathrm{M} \mathrm{Li}_{2} \mathrm{SO}_{4}$ & 0 & 0 & 0.099 & 0.026 \\
\hline $0.5 \mathrm{M} \mathrm{MgSO}_{4}$ & 0 & 0 & 0 & 0 \\
\hline
\end{tabular}

and $9.0,0.2 \mathrm{M}$ sodium borate- $\mathrm{NaOH}$ buffer for $\mathrm{pH} 10.0$. The cell suspension $(3.0 \mathrm{ml})$ was incubated at $40^{\circ} \mathrm{C}$ for $30 \mathrm{~min}$. As shown in Fig. 1, an optimum $\mathrm{pH}$ for the autolytic activity was near $\mathrm{pH} 7-9$.

\section{Optimum Temperature for Autolytic Activity}

Strain V37 cells grown in the medium containing $0.5 \mathrm{M} \mathrm{NaCl}$ were washed once in $0.05 \mathrm{M}$ Tris- $\mathrm{HCl}$ buffer ( $\mathrm{pH} 7.0)$, and resuspended in similar buffer. The cell suspension was incubated at various temperatures ranging from $10^{\circ} \mathrm{C}$ to $70^{\circ} \mathrm{C}$ for $30 \mathrm{~min}$. The autolytic activity showed an optimum temperature of near $40^{\circ} \mathrm{C}$ (Fig. 2).

Effect of Inorganic Salt on the Autolysis of Strain V37 Cells Grown in the Medium Containing $0.5 \mathrm{M}$ $\mathrm{NaCl}, \mathrm{KCl}, \mathrm{MgCl}_{2}$ or No Inorganic Salt

Strain V37 cells were grown in the medium containing $0.5 \mathrm{M} \mathrm{NaCl}, \mathrm{KCl}$ or $\mathrm{MgCl}_{2}$ and also in the medium without addition of inorganic salt. The cells were washed once in $0.05 \mathrm{M}$ Tris- $\mathrm{HCl}$ buffer (pH 7.0) containing $0.5 \mathrm{M}$ inorganic salt to be tested, and resuspended in similar buffer. The cell suspension was incubated at $40^{\circ} \mathrm{C}$ for $30 \mathrm{~min}$. It can be seen in Table 1 that autolysis of strain V37 cells slightly decreased with the addition of $0.5 \mathrm{M}$ monovalent cations, such as $\mathrm{Na}^{+}, \mathrm{K}^{+}, \mathrm{Li}^{+}$, 


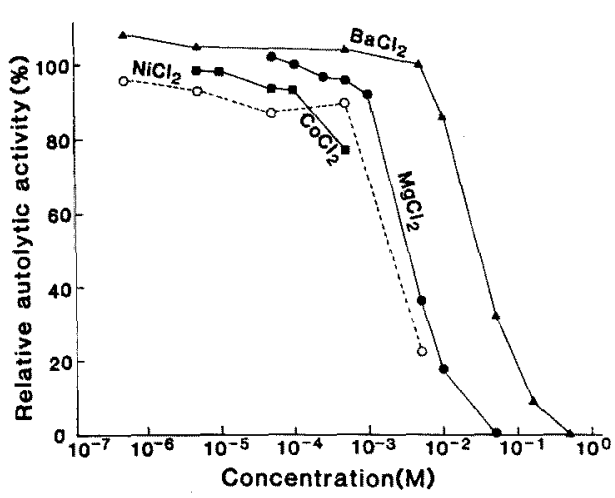

Fig. 3. Effect of low concentrations of divalent cations on the autolytic activity of strain V37 cells grown in polypepton-yeast extract medium containing $0.5 \mathrm{M} \mathrm{NaCl}$.

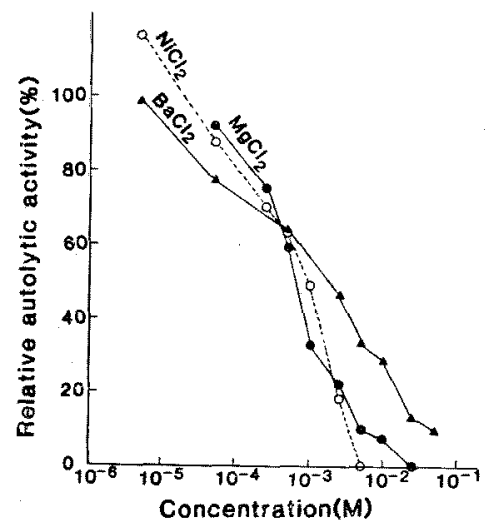

Fig. 4. Effect of low concentrations of divalent cations on the autolytic activity of strain V37 cells grown in polypepton-yeast extract medium without inorganic salt.

$\mathrm{Cs}^{+}, \mathrm{Rb}^{+}$and $\mathrm{NH}_{4}{ }^{+}$. However, $0.5 \mathrm{M}$ divalent cations, such as $\mathrm{Mg}^{2+}, \mathrm{Ca}^{2+}$ and $\mathrm{Ba}^{2+}$ completely inhibited autolysis.

The cells grown in the medium containing $0.5 \mathrm{M}$ $\mathrm{NaCl}$ or $\mathrm{KCl}$ exhibited higher autolytic activity than the cells grown in the medium containing $0.5 \mathrm{M} \mathrm{MgCl}_{2}$ or without addition of inorganic salt.

\section{Effect of Concentrations of Divalent Cations on the} Autolytic Activity of Strain V37 Cells

Low concentration $(0.05 \mathrm{M})$ of $\mathrm{MgCl}_{2}$ significantly inhibited the autolytic activity of strain V37 cells grown in the medium containing $0.5 \mathrm{M}$ $\mathrm{NaCl}{ }^{\natural)}$

In order to demonstrate the inhibitory effect of concentrations of divalent cations on the autolysis

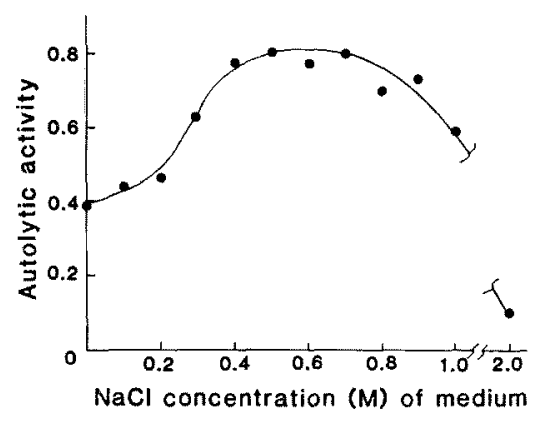

Fig. 5. Autolysis of strain V37 cells grown in polypepton-yeast extract media containing different concentrations of $\mathrm{NaCl}$.

of strain V37 cells, strain V37 cells were grown in the medium containing $0.5 \mathrm{M} \mathrm{NaCl}$ or without inorganic salt. The cells were washed once in $0.05 \mathrm{M}$ Tris- $\mathrm{HCl}$ buffer ( $\mathrm{pH} \mathrm{7.0)}$ containing various concentrations of $\mathrm{NiCl}_{2}, \mathrm{CoCl}_{2}, \mathrm{BaCl}_{2}$ or $\mathrm{MgCl}_{2}$, and resuspended in similar buffer. Autolytic activity was expressed as $\%$ of the activity of the cell suspension without addition of inorganic salt. Autolysis of the cells grown in the medium containing $0.5 \mathrm{M} \mathrm{NaCl}$ was inhibited by $\mathrm{Ba}^{2+}, \mathrm{Mg}^{2+}$, $\mathrm{Co}^{2+}$ and $\mathrm{Ni}^{2+}$ at more than concentration of $10^{-3} \mathrm{M}$ (Fig. 3). However, the cells grown in the medium without inorganic salts were more sensitive to lower concentrations of $\mathrm{Mg}^{2+}, \mathrm{Ni}^{2+}$ and $\mathrm{Ba}^{2+}$, for preventing autolysis (Fig. 4).

Autolysis of Strain V37 Cells Grown in the Media Containing Different Concentrations of $\mathrm{NaCl}$

In order to compare the ability of autolysis of the cells grown in the media containing different concentrations of $\mathrm{NaCl}$, strain $\mathrm{V} 37$ cells were grown in the different media containing $0-2.0 \mathrm{M}$ $\mathrm{NaCl}$. The cells were washed once in $0.05 \mathrm{M}$ Tris$\mathrm{HCl}$ buffer (pH 7.0), and resuspended in similar buffer. As shown in Fig. 5, the cells grown in the media containing $0.4-0.9 \mathrm{M} \mathrm{NaCl}$ exhibited high autolytic activity.

Effect of $\mathrm{NaCl}$ Concentration on the Autolytic Activity of Strain V37 Cells Grown in the Media Containing Different Concentrations of $\mathrm{NaCl}$

Strain V37 cells were grown in the media containing $0-1.0 \mathrm{M} \mathrm{NaCl}$. The cells were washed once in $0.05 \mathrm{M}$ Tris-HCl buffer ( $\mathrm{pH} \mathrm{7.0)}$ containing 0 , $0.1,0.2,0.3,0.4$ or $0.5 \mathrm{M} \mathrm{NaCl}$, and resuspended in similar buffer. Change in the optical density at $570 \mathrm{~nm}$ of the cell suspension was followed at $40^{\circ} \mathrm{C}$ for upto $10 \mathrm{~min}$ in a Hitachi spectrophotometer model 330. Autolytic activity was expressed 


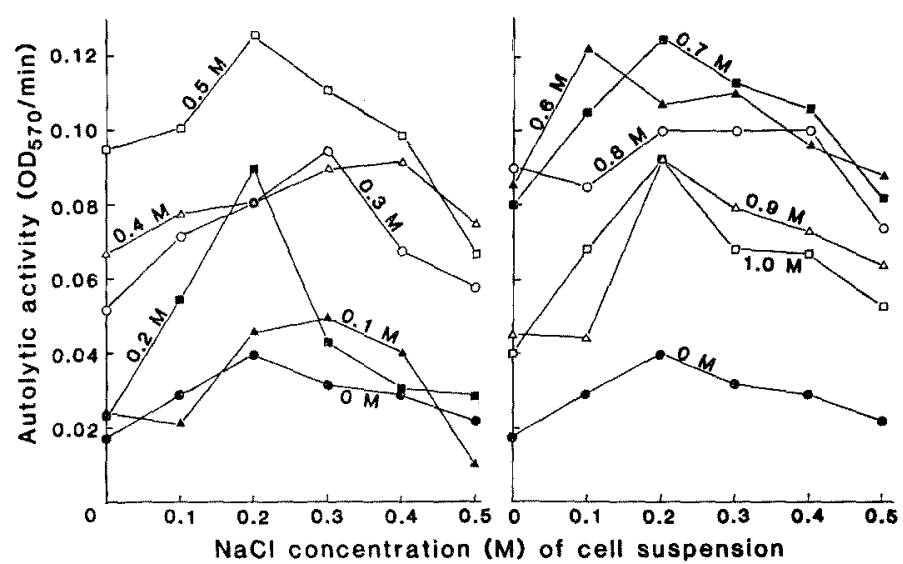

Fig. 6. Effect of $\mathrm{NaCl}$ concentration on the autolytic activity of strain V37 cells grown in polypepton-yeast extract media containing different concentrations of $\mathrm{NaCl}$.

Cells grown in the media containing $0 \mathrm{M}(\bullet), 0.1 \mathrm{M}(\mathrm{A}), 0.2 \mathrm{M}(\mathbf{m}), 0.3 \mathrm{M}(\mathrm{O}), 0.4 \mathrm{M}(\Delta)$, $0.5 \mathrm{M}(\square), 0.6 \mathrm{M}(\Delta), 0.7 \mathrm{M}(\mathbf{\square}), 0.8 \mathrm{M}(0), 0.9 \mathrm{M}(\triangle)$ and $1.0 \mathrm{M}(\square) \mathrm{NaCl}$.

as a decrease in $O_{\text {sro }}$ per min. As shown in Fig. 6, autolysis of the cells grown in the media containing $\mathrm{NaCl}$ at concentrations from 0 to $1.0 \mathrm{M}$ was slightly activated by low concentrations of $\mathrm{NaCl}(0.2-0.3 \mathrm{M})$.

\section{Discussion}

The effect of inorganic salt on the autolysis has been reported for some microorganisms. Ogata and Hongo ${ }^{10}$ described that the growing cells of Clostridium saccharoperbutylacetonicum were lysed by the addition of univalent cations such as $\mathrm{Na}^{+}$, $\mathrm{K}^{+}, \mathrm{Rb}^{+}, \mathrm{Cs}^{+}, \mathrm{Li}^{+}$and $\mathrm{NH}_{4}^{+}$. According to them, most rapid lysis of the cells occurred during the middle of the exponential phase, when 0.3 to $0.5 \mathrm{M} \mathrm{Na}^{+}$was used. Bivalent cations such as $\mathrm{Ca}^{2+}, \mathrm{Mg}^{2+}, \mathrm{Ba}^{2+}, \mathrm{Co}^{2+}$ and $\mathrm{Ni}^{2+}$ at above $0.005 \mathrm{M}$ inhibited $\mathrm{Na}^{+}$-induced autolysis. Maximum rate of cell lysis was at $\mathrm{pH} 5.7$ to 6.0 and at $35^{\circ} \mathrm{C} .11$ They suggested that $\mathrm{NaCl}$-induced lysis was closely related to an autolytic enzyme system. ${ }^{11)}$ Sato et al. ${ }^{12)}$ showed that the logarithmic phase cells of Escherichia coli lost their colonyforming ability when the cells were suspended in Tris-HCl buffer containing $0.15 \mathrm{M} \mathrm{NaCl}$. The presence of $\mathrm{Ca}^{2+}$ or $\mathrm{Mg}^{2+}$ protected the cells from the injurious effect of $\mathrm{NaCl}$. Iijima and Ikeda ${ }^{13}$ also observed a similar sensitivity to $0.15 \mathrm{M} \mathrm{NaCl}$ in Bacillus subtilis. Gilpin et al. ${ }^{14)}$ demonstrated that mutant cells of Staphylococcus aureus were autolysed to the same extent when suspended in $0.05 \mathrm{M}$ Tris- $\mathrm{HCl}$ buffer $(\mathrm{pH} 7.0)$ containing $1.0 \mathrm{M}$ $\mathrm{NaCl}, \mathrm{KCl}, \mathrm{NaBr}$ or $\mathrm{NH}_{4} \mathrm{Cl}$ and incubated at $37^{\circ} \mathrm{C}$ for $30 \mathrm{~min}$. Equivalent and higher molarities of $\mathrm{NaNO}_{3}, \mathrm{Na}_{2} \mathrm{SO}_{4},\left(\mathrm{NH}_{4}\right)_{2} \mathrm{SO}_{4}, \mathrm{NH}_{4} \mathrm{NO}_{8}, \mathrm{LiCl}$, urea, sucrose and divalent cations such as $\mathrm{MgCl}_{2}$ had no effect on the autolysis. The $\mathrm{NaCl}$-induced lysis was optimum at $\mathrm{pH} 6.5$ to 7.0 , temperature $37^{\circ} \mathrm{C}$ and $\mathrm{NaCl}$ concentration $1.0 \mathrm{M}$. Exposure to $1.0 \mathrm{M} \mathrm{NaCl}$ sensitized the cells so that subsequent autolysis may occur even in the absence of salt. Gilpin et al. ${ }^{14)}$ suggested that $\mathrm{NaCl}$-induced autolysis primarily involved $\mathrm{N}$-acyl-muramyl-L-alanine amidase.

No autolysis of strain V37 cells was observed during further incubation when $0.5 \mathrm{M} \mathrm{NaCl}$ (final concentration) was added to the growing cultures without $\mathrm{NaCl}^{7}$ ) The mechanism of autolysis of strain V 37 cells seemed to be different from that reported by Ogata and Hongo..$^{10,11)}$ However, a remarkable autolytic activity was detected when the cells grown in the medium containing $\mathrm{NaCl}$ or $\mathrm{KCl}$ were suspended in $0.05 \mathrm{M}$ Tris- $\mathrm{HCl}$ buffer (pH 7.0) (Table 1). The optimum $\mathrm{pH}$ and temperature for the autolysis of strain V37 cells were 7 to 9 and $40^{\circ} \mathrm{C}$, respectively (Figs. 1 and 2). Autolytic activity of strain $\mathrm{V} 37$ cells slightly increased in the presence of $0.2-0.3 \mathrm{M} \mathrm{NaCl}$ (Fig. 6), but was rather inhibited by $1.0 \mathrm{M} \mathrm{NaCl}{ }^{9)}$ This was also different from the result of Gilpin et al. ${ }^{14)}$ The cells grown in the medium containing $0.5 \mathrm{M} \mathrm{NaCl}$ or $\mathrm{KCl}$ increased more autolytic activity than those grown in the medium containing $0.5 \mathrm{M} \mathrm{MgCl}_{2}$ or without inorganic salt (Table 1). NaCl-enhanced autolysis (Fig. 5) and protection effect of divalent cations on the cell lysis (Figs. 3 and 4) were similar 
to the observations reported up to date..$^{10-14)}$

It is not yet clear about the relation between production of bacteriolytic enzyme and autolysis of strain V37 cells. Further study will be necessary in order to demonstrate the mechanism of autolysis of strain V37 cells.

\section{References}

1) C. Forsberg and H. J. Rogers: Nature, 229, 272-273 (1971).

2) D.P. Fan: J. Bacteriol., 103, $494-499$ (1970).

3) C. R. Stewart and J. Marmur: J. Bacteriol, 101, 449-455 (1970).

4) S. Ogata: Nippon Nögeikagaku Kaishi, 50, R69R77 (1976).

5) I. Sugahara, K. Hayashi, T. Kimura, Y. Suzuki, H. Toyoda, and A. Matsuoka: Bull. Fac. Fish., Mie Univ., 7, 9-27 (1980).

6) I. Sugahara, K. Hayashi, T. Kimura, A. Matsu- oka, C. Jinno, and S. Yamanaka: Bull. Fac. Fish., Mie Univ., 8, 49-60 (1981).

7) I. Sugahara, K. Hayashi, T. Kimura, H. Toyoda, A. Matsuoka, and S. Yamanaka: Bull. Japan. Soc. Sci. Fish., 50, 1051-1055 (1984).

8) I. Sugahara, K. Hayashi, and T. Kimura: Bull. Fac. Fish., Mie Univ., 9, 31-37 (1982).

9) I. Sugahara, K. Hayashi, T. Kimura, and $C$. Jinno: Bull. Fac. Fish., Mie Univ., 10, 33-39 (1983).

10) S. Ogata and M. Hongo: J. Gen. Appl. Microbiol., 19, 251-261 (1973).

11) S. Ogata and M. Hongo: J. Gen. Microbiol., 81, 315-323 (1974).

12) T. Sato, Y. Suzuki, K. Izaki, and H. Takahashi: J. Gen. Appl. Microbiol., 17, 371-382 (1971).

13) T. Iijima and Y. Ikeda: J. Gen. Appl. Microbiol., 15, 453-461 (1969).

14) R. W. Gilpin, A. N. Chatterjee, and F. E. Young: J. Bacteriol, 111, 272-283 (1972). 